\title{
IMPACT OF ORGANIZATIONAL CULTURE AND LEADERSHIP STYLES ON EMPLOYEE PERFORMANCE: A RESEARCH STUDY ON THE BANKING INDUSTRY
}

\author{
DOI: 10.17261/Pressacademia.2020.1187 \\ RJBM-V.7-ISS.1-2020(5)-p.45-55
}

\section{Oznur Ozcan ${ }^{1}$, Ilkay Ozturk ${ }^{2}$}

${ }^{1}$ Bahcesehir University, Institute of Social Sciences, Besiktas, Istanbul, Turkey. Oznur.ozcan34@gmail.com ORCID:0000-0002-5777-5662

${ }^{2}$ Bahcesehir University, Institute of Social Sciences, Besiktas, Istanbul, Turkey. Ilkay.ozturk@vsh.bau.edu.tr, ORCID: 0000-0002-9867-9108

\section{To cite this document}

Ozcan, O., Ozturk, I., (2020). Impact of organizational culture and leadership styles on employee performance: a research study on the banking industry. Research Journal of Business and Management (RJBM), V.7(1), p.45-55.

Permemant link to this document: http://doi.org/10.17261/Pressacademia.2020.1187

Copyright: Published by PressAcademia and limited licenced re-use rights only.

\begin{abstract}
Purpose- The aim of this study is to assess the influence of organizational culture on leadership styles and investigate how employee performance is affected by the relation between these two factors.

Methodology-This study follows a quantitative research methodology. A survey data has been yielded from the employees of a private bank's head office and analyzed using SPSS 24 . The questionnaire in this study comprises four parts. The first part of the questionnaire contains questions on demographic information, the second part is the Multifactor Leadership Questionnaire (MLP), In the third part, the Organizational Culture Assessment Instrument was used in order to determine employee perceptions and the final part of the questionnaire is the individual performance assessment tool. The research attempts to find an answer to the question, "Is employee performance influenced by organizational culture and leadership style?"

Findings- The correlation analysis results show that there is a positive correlation between transactional leadership and market culture but a negative correlation both hierarchy and clan-adhocracy culture. Between transactional-transformational leadership style and all culture types there is positive correlation. Between all culture types and individual performance there is positive correlation. Finally, according to the correlation analysis between leadership styles and individual performance; there is a positive correlation between transactional-transformational leadership and individual performance whereas there is a negative correlation between transactional leadership and individual performance. The effect of all cultures types on transformational leadership style is statistically significant. The effect of hierarchy culture and transformational leadership on individual performance is statistically significant.

Conclusion- Organizational culture is a factor that plays important roles on both leadership styles and employee performance. The leadership styles demonstrated in an organization also exert a major impact on the performance of employees. The results of this research suggest that the market type and the hierarchy type of organizational culture increase employee performance. This finding implies that employees perform relatively better when tasks are defined in line with rules, procedures, and policies, goals are openly shared with them, they are encouraged to compete over performance criteria, and are rewarded based on their performance. The clan-adhocracy culture is also observed to have a positive influence on employee performance.
\end{abstract}

Keywords: Organizational culture, transformational leadership, transactional leadership, employee performance, banking industry. JEL Codes: M10, M12, M14

\section{INTRODUCTION}

In the world today, with new technologies introduced every day and globalization at its peak, we are subject to an endless chain of swift changes in all areas of life. Organizations aim and compete to survive and grow in this ongoing process of flux unfolding in the social, political, and cultural arenas. The culture of an organization therefore is also in flux, forced to be structured and to restructure itself in different ways over time according to whatever essential change is currently happening in the world. 
Organizational culture is known to have an impact on both how employees respond to change as well as the level of their resistance to it. Under circumstances of change, managers must demonstrate openness to novelty and work out ways to get through their teams' phases of resistance to change. Every organization owns a culture unique to itself. Made up of written or unwritten rules, beliefs and values, the organizational culture brings together individuals of differing opinions, beliefs, and values around a shared goal and thus helps the organization attain its goals.

Although new technologies usher in effortless solutions to replace many business and organizational processes, the significance of the human factor in organizations is still unarguably decisive in leading them to success. Among the organizations which have similar technologies, financial resources or other material resources, human resources then become the defining component of the organization, creating competitive advantage through the addition of value to the organization. A concept closely tied to organizational culture is leadership. While organizational culture surely has an influence on the leadership skills of individuals within the organization, leaders may also shape the entire organizational culture as well (Erdem and Dikici 2009, p. 210). This strong interaction has an impact on employee performance, which in turn plays an important role in the organization's sustainability and its ability to gain competitive advantage. Knowing that, organizations today invest more and more in human capital. They attempt to increase productivity by supporting employees' personal development and boosting their motivation.

The leadership qualities of managers play an important role in achieving these aims. To name a concrete example, throughout history, banks have found themselves, as they do now, in intense competition within the finance industry with no other choice than to adapt to the world changing and growing faster than ever, responding to the needs and demands of changing consumer profiles, developing new products and services, and aligning their employees with new processes. The style adopted by leaders, in this context, makes a great difference in boosting or bringing down employee performance.

Given the preceding discussion, the aim of this study is to assess the influence of organizational culture on leadership styles and to investigate further how the relation between these two concepts affects employee performance. Accordingly, the previous research on organizational culture, leadership and employee performance is given in the first part of the study. Then, in the second part, the methodology, research questions and findings of the research is presented.

\section{PREVIOUS RESEARCH ON ORGANIZATIONAL CULTURE, LEADERSHIP AND EMPLOYEE PERFORMANCE}

Kılıç (2006) investigated the impact of leadership styles and organizational culture on performance by studying teacher performance as subject to teachers' perceptions on leadership styles and the dominant culture in the organization. The results imply that school principals demonstrate the transformational leadership style more often than the interactive leadership style and that a constructive organizational culture is prevalent. According to the findings of this study, the transformational leadership style has a more powerful influence on performance. In addition, the constructive culture was found to have more positive influence on performance in comparison to the defensive organizational culture. On the other hand, the laissez-faire leadership style was found not to be effective on performance in schools, whether the organizational culture is constructive or defensive.

Çıpa (2014) conducted a survey with teachers and students from educational institutions operating in one of Istanbul's districts, using the face-to-face questionnaire method. In this study, the transformational leadership style - found to be the dominant style in schools and organizational culture - was studied to find out if it was effective on teacher performance. The results of the study indicate that teacher performance is directly and positively influenced by the transformational leadership style and organizational culture.

In Şahin (2016)'s study, the leadership styles of managers employed in Istanbul private schools were examined for their influence on the performance of teachers. Horizontal communication models, as opposed to hierarchies, were found to contribute to the relatively higher teacher performance observed in institutions.

Karayalçın (2009) conducted a study in 2008 with employees working at a private foreign bank's various branches, operating in Istanbul. The instrumental and supportive leadership styles were identified for examination together with four types of organizational culture: competitive, innovative, bureaucratic, and community. The results indicate that organizational performance is directly and significantly related to the community type of organizational culture and the participant leadership style. Öztop (2008)'s study focuses on the relation of leadership style to the type of organizational culture and the impact of this relationship on quantitative performance, in a study conducted with employees from production companies of 50 or more employees, operating in a district of Istanbul. 
The charismatic, paternalist, operational, and transformational leadership styles were selected to be examined in relation to the organizational culture types of adhocracy, clan, bureaucracy, and market culture. The results indicate that only the transformational leadership style and the clan type of organizational culture influence quantitative performance positively. Furthermore, charismatic leadership was found to have a strong and positive impact on adhocracy culture, as does operational leadership on bureaucracy and market cultures. Adhocracy, clan, and market cultures were found to be positively influenced by transformational leadership.

Anderman et al. (1991), in their article "Teacher Commitment and Job Satisfaction: The Role of School Culture and Principal Leadership", present three analyses scrutinizing the relation between teachers' perception of school leadership, school culture, and teacher satisfaction and commitment. In the first, a multiple regression analysis was conducted, resulting in findings which support the proposition that having a school culture based on recognizing success and successful people is correlated to the satisfaction and commitment of teachers. The second one, too, is a multiple regression analysis, where different leader behaviors were found to promote different cultures in the school. In the last one, different leadership behaviors were analyzed for their effect on teacher satisfaction and commitment, with results supporting the theoretical assumption that the leadership styles of principals lead to different work environments in schools.

In the study "The effect of leadership styles and organizational culture on organizational performance of the public sector in Saudi Arabia", Omira (2015) investigates the effect of leadership styles and organizational culture on organizational performance of the public sector in Saudi Arabia. Public institutions in Saudi Arabia were associated with low performance and poor management. In this quantitative research, cross-sectional data of 400 employees working in 16 ministries of the Saudi Arabia government were obtained. Results indicate the positive influence of transactional and transformational leadership on organizational performance.

Marks (2002) explores teachers' perceptions of the leadership style exercised by principals in Virginia public schools in her article, "A study of two leadership styles and school cultural norms in small middle schools". The results point to a distinction between principals and teachers regarding their perceptions of leadership style. Also, a significant and positive correlation was found to exist between the school culture perceived by teachers and the transformational leadership style demonstrated by managers.

With the aim of assessing the impact of leadership styles on employee performance and the level of commitment, Doğanay (2014) carried out research in Başakşehir Municipality, Istanbul, where task oriented and employee oriented leadership styles were found to have a significant positive influence on employee performance, though results indicated that the people oriented leadership style has a stronger impact on performance.

In a study conducted with the employees of a courier company's Istanbul branches, Aslan (2017) investigated the issue of performance as determined by the leadership styles of managers. It was observed that transformational leadership had a stronger influence on employee performance in comparison to operational leadership.

Gül (2016) investigated the leadership styles of leaders in public institutions in terms of their influence on types of organizational culture as perceived by employees. The study found that the autocratic style of leadership has a positive influence only on market culture, while adhocracy and clan cultures are positively influenced by the transformational leadership style. In addition, the paternalist style of leadership was found to have a positive influence on clan and market cultures. Akman et al. (2015) focused on the influence of leadership styles on employee performance, observing a moderately significant correlation between employee performance and the autocratic, democratic, and humanistic styles of leadership.

Barney (1986) also found results indicating that the authenticity of an organization's culture is effective in gaining competitive advantage. Bozoğlan (2010) states that organizational culture has a positive contribution to the organization's performance, based on the results of a research conducted in a Tesco Kipa establishment, assessing the organizational culture's influence on performance criteria.Ay and Keleş (2017) found, in their study with the managers working at a University Hospital, that the transformational leadership style had a positive influence on job performance, leading to an increase in performance. Zakari et al. (2013) studied nine banks in Ghana, where they scrutinized the relation between organizational culture and performance. The results indicated that although banks can be clearly differentiated by the features of their organizational culture, there is not much difference in terms of performance. Additionally, a positive correlation was found between organizational culture and performance in many other studies (Öztürk, 2014; Erdil, et al., 2005; Tüfekçi, 2012; Barut and Onay, 2018; Bakan, 2009; Mamatoğlu, 2005; Demirel, 2017; Çekmecelioğlu, 2014).

In contrast, some studies demonstrate that there is not a significant correlation between the dimensions of transformational leadership and employee performance (İncirkuş, 2012; Güven, 2018; Arman and Arpacı, 2014; Balay et al., 2013). 


\section{RESEARCH METHOD}

This study follows a quantitative research methodology. The questionnaire technique was used as a survey method. In survey research, the objective is to determine whether there is correlation between the defined variables (Yıldırım 2000, p. 56). The questionnaire in this study comprises four parts. A Five Point Likert Scale was used for all questions, requiring answers on a scale from (1) "strongly disagree" to (5) "strongly agree".

The first part of the questionnaire is the personal information form, which contains questions on demographic information about employees such as gender, level of education, age, and professional experience.

The second part is the Multifactor Leadership Questionnaire (MLP), which was developed by Avalio and Bass (1999) to identify the perceived leadership styles of employees. The Turkish adaptation of the questionnaire by Yurtkoru (2001) was used. Out of the 36 statements in the questionnaire, the first 20 statements assess transformational leadership and the last 16 assess transactional leadership. The dimensions of transactional leadership are defined as contingent rewards, active management by exceptions, passive management by exception, and laissez-faire. The dimensions of transformational leadership are identified as inspirational motivation, charisma or idealized influence, individual consideration, and intellectual stimulation.

In the third part, the "Organizational Culture Assessment Instrument" was used in order to determine employee perceptions on the four organizational culture types set by Cameron and Quinn (1999) in their "Competing Values Model". The questionnaire consists of 16 questions. The first four questions assess the clan type of culture, the next four questions assess the adhocracy type, the third set of four questions assess the hierarchy type, and the final four questions assess the market type.

The fourth and final part of the questionnaire is the individual performance assessment tool used by Tayfun and Çatır (2013). This tool is made up of 6 questions which require employees to comment on their own performance.

The research universe is defined as white-collar employees working at a private bank's head office. The research sample consists of 287 people belonging to this universe, selected using the random sampling method.

\subsection{Research Model and Variables}

The independent variables of the research are organizational culture and leadership style; the dependent variable is employee performance. The interactions of these variables are demonstrated in the model presented in Figure 1.

Figure 1: The Research Model

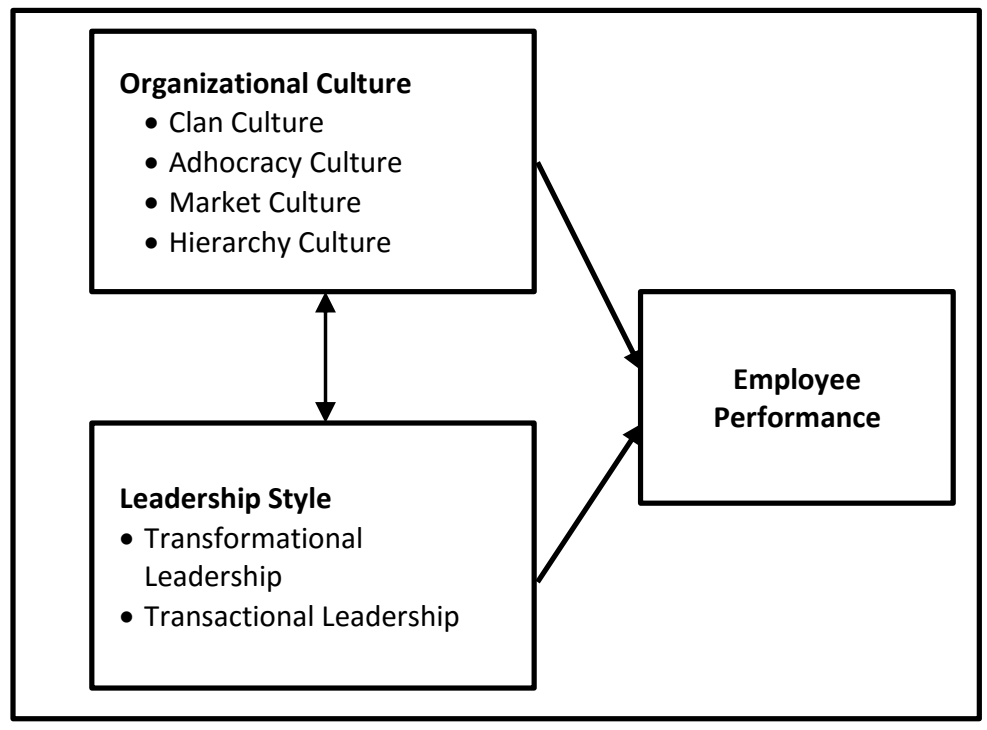




\subsection{The Research Question and Hypotheses}

The research attempts to find an answer to the question, "Is employee performance influenced by organizational culture and leadership style?"

The hypotheses tested in the scope of this research are as follows:

$\mathbf{H}_{1}$ : There is a significant correlation between organizational culture, leadership style and individual performance.

$\mathbf{H}_{1 \mathrm{a}}$ : There is a significant correlation between organizational culture and individual performance.

$\mathbf{H}_{1 b}$ : There is a significant correlation between organizational culture and leadership style.

$\mathbf{H}_{1 \mathbf{c}}$ : There is a significant correlation between leadership style and individual performance.

$\mathbf{H}_{\mathbf{2}}$ : Organizational culture has an influence on leadership style.

$\mathbf{H}_{3}$ : Leadership style and organizational culture influence individual performance.

\section{FINDINGS}

68 percent of participants were men and 32 percent were women. In terms of their level of education, 74 percent of participants were university graduates, 21 percent had a master's degree, 1 percent had received their doctorate, and the remaining 4 percent had graduated from other schools. The age distribution showed that 54 percent of participants were aged 20-35 years, 44 percent were aged 36-45 years, and 3 percent were aged 46-55 years. Lastly, 21 percent of participants had 0-5 years of professional experience, 22 percent had 6-10 years of experience, 40 percent had 11-15 years of experience, 11 percent had 16-20 years of experience, and 6 percent had over 20 years of experience.

The first 20 questions of the leadership questionnaire measure transformational leadership while the remaining 16 measure transactional leadership. 3 statements were removed due to low factor loading and the remaining 33 questions were recategorized into two factors. The factor analysis results caused the dimensions to merge, thus transformational leadership was redefined as transformational-transactional leadership.

In order to check if the data were suited for factor analysis, the Kaisen-Meyer-Olkin (KMO) measure of sampling adequacy and the Bartlett Test for Sphericity were performed. KMO scores range between 0 and 1 . A case where the KMO score is 1 indicates a situation where variables can be predicted without error. A score below 0.50 on the Kaiser-Meyer-Olkin test implies that a factor analysis will not be valuable and should not be continued (Bülbül and Köse 2010, p. 46). In this scope, the research data were found to be suitable for factor analysis, based on the value presented in Table 1 . The total explained variance calculated in this research was 63 percent. Data regarding the factor analysis are presented in Table 1.

Table 1: Results Reflecting the Leadership Questionnaire's Suitability for Factor Analysis

\begin{tabular}{|l|l|l|}
\hline \multicolumn{2}{|l|}{ Kaiser-Meyer-Olkin (KMO) Measure of Sampling Adequacy } & 0.957 \\
\hline Bartlett Test & Chi-Square & 8372.437 \\
\hline & Sd & 528 \\
\hline & Sig. & 0.000 \\
\hline$(p<0.01)$ & \\
\hline
\end{tabular}

In the culture assessment instrument, the first four questions assess the clan type of culture, the next four questions assess the adhocracy type, the third set of four questions assess the hierarchy type, and the final four questions assess the market type. As a result of the factor analysis, the clan and adhocracy dimensions of organizational culture were merged. 4 items were removed from the culture assessment due to low factor loading, and the remaining 12 items were re-categorized into three factors. Factor analysis information regarding the culture assessment is presented in Table 2; according to which the data were found suitable for factor analysis. The total explained variance in this research was calculated as 73 percent.

Table 2: Results Reflecting the Culture Assessment's Suitability for Factor Analysis

\begin{tabular}{|l|l|l|}
\hline \multicolumn{2}{|l|}{ Kaiser-Mayer-Olkin (KMO) Measure of Sampling Adequacy } & 0.877 \\
\hline \multirow{2}{*}{ Bartlett Test } & Chi-Square & 2012.588 \\
\cline { 2 - 3 } & Sd & 66 \\
\hline
\end{tabular}




\begin{tabular}{|l|l|l|}
\hline & Sig. & 0.000 \\
\hline$(p<0.01)$ & \\
\hline
\end{tabular}

The performance evaluation tool used in the research was analyzed for reliability and a factor analysis was performed in order to identify its dimensions. The factor analysis results showed clustering around a single dimension in compliance with the original version. Table 3 shows the performance evaluation tool data, which was found suitable for factor analysis. The total explained variance in this research was calculated as 62 percent.

Table 3: Results Reflecting the Suitability Of The Performance Evaluation Tool for Factor Analysis

\begin{tabular}{|l|c|c|}
\hline Kaiser-Mayer-Olkin (KMO) Measure of Sampling Adequacy & 0.876 \\
\hline \multirow{2}{*}{ Bartlett Test } & Chi-Square & 792.738 \\
\cline { 2 - 3 } & Sd & 15 \\
\cline { 2 - 3 } & Sig. & 0.000 \\
\hline$(p<0.01)$ & \multicolumn{2}{|c|}{} \\
\hline
\end{tabular}

When identifying the number of dimensions that emerge as a result of factor analysis, the number of factors selected must be defined to ensure that a certain level of total explained variance can be achieved. It is stated that a factor loading of 0.70 and above is sufficient (Büyüköztürk, 2011). The confidence coefficient is a value between 0.00 and 1.00. The Cronbach Alpha value, a measure of the confidence coefficient, was calculated as 0.943 , indicating a significantly high confidence level. Table 4 presents the results of the reliability test.

Table 4: Reliability Statistics

\begin{tabular}{|r|r|}
\hline \multicolumn{2}{|c|}{ Reliability Statistics } \\
\hline Cronbach's Alpha & $\begin{array}{c}\text { Total Number of } \\
\text { Items }\end{array}$ \\
\hline 0.943 & \\
\hline
\end{tabular}

The data pertaining to the variables of leadership, culture, and individual performance were tested for their compliance to normal distribution. The Kolmogorov-Simirnov test was performed for this purpose, and the results indicate that the data are not normally distributed. It is assumed that the data are not normally distributed for all groups due to the "Sig." value below 0.05 on the Shapiro-Wilk test. The results of the normality test are demonstrated in Table 5.

Table 5: Normality Test Results

\begin{tabular}{|l|c|c|c|c|c|c|}
\hline \multirow{2}{*}{} & \multicolumn{3}{|c|}{ Kolmogorov-Simirnov $^{\mathbf{a}}$} & \multicolumn{3}{c|}{ Shapiro-Wilk } \\
\cline { 2 - 7 } & Statistic & df & Sig. & Statistic & df & Sig. \\
\hline Leadership & 0.067 & 275 & 0.004 & 0.974 & 275 & 0.000 \\
\hline Performance & 0.155 & 275 & 0.000 & 0.853 & 275 & 0.000 \\
\hline Culture & 0.068 & 275 & 0.004 & 0.985 & 275 & 0.005 \\
\hline
\end{tabular}

\subsection{Correlation Analysis Results}

The analysis results show that between transactional leadership and both hierarchy and clan-adhocracy culture there is a negative correlation $(-0,180)$. On the other hand, between transactional leadership and market culture there is a positive correlation $(0,073)$. Between transactional-transformational leadership style and respectively hierarchy culture $(0,323)$, market culture $(0,193)$ and clan-adhocracy culture $(0,489)$ there is positive correlation.

Secondly the results of the correlation analysis between culture types and individual performance shows that there is positive correlation between performance and hierarchy culture $(0,259)$, market culture $(0,156)$ and clan-adhocracy culture $(0,317)$.

Finally, according to the correlation analysis between leadership styles and individual performance; there is a positive correlation between transactional-transformational leadership and individual performance $(0,462)$ whereas there is a negative correlation between transactional leadership and individual performance $(-0,240)$. 
Table 6 presents the Spearman correlation coefficients for the research variables.

Table 6: Correlation Analysis

\begin{tabular}{|c|c|c|c|c|c|c|c|}
\hline & 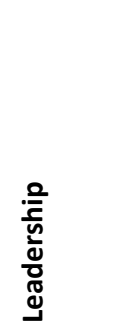 & 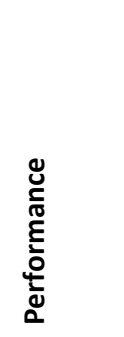 & 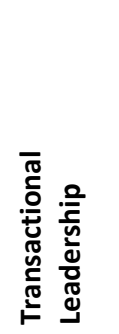 & 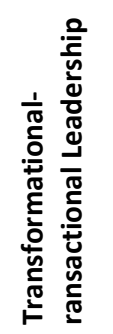 & 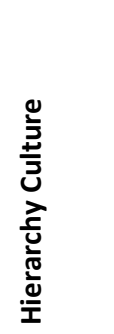 & 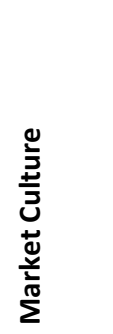 & 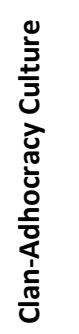 \\
\hline Leadership & 1.000 & & & & & & \\
\hline Performance & $0.414^{* *}$ & 1.000 & & & & & \\
\hline Transactional Leadership & $-0.121^{*}$ & $-0.240^{* *}$ & 1.000 & & & & \\
\hline $\begin{array}{l}\text { Transformational- } \\
\text { Transactional Leadership }\end{array}$ & $0.939^{* *}$ & $0.462^{* *}$ & $-0.398^{* *}$ & 1.000 & & & \\
\hline Hierarchy Culture & $0.295^{* *}$ & $0.259^{* *}$ & $-0.180^{* *}$ & $0.323^{* *}$ & 1.000 & & \\
\hline Market Culture & $0.231^{* *}$ & $0.156^{* *}$ & 0.073 & $0.193^{* *}$ & $0.401^{* *}$ & 1.000 & \\
\hline Clan-Adhocracy Culture & $0.476^{* *}$ & $0.317^{* *}$ & $-0.180^{* *}$ & $0.489^{* *}$ & $0.512^{* *}$ & $0.343^{* *}$ & 1.000 \\
\hline
\end{tabular}

\subsection{Regression Analysis Results}

$\mathbf{H}_{2:}$ Organizational culture has an influence on leadership style.

Table 7 demonstrates the relationship between the variables. A regression analysis was performed to measure the effect of "Organizational Culture" on "Leadership Style".

Table 7: Regression Analysis between Organizational Culture and Leadership Style

\begin{tabular}{|l|c|c|c|c|c|c|}
\hline \multicolumn{2}{|l|}{ Dependent Variable: Transformational Leadership } & \multicolumn{2}{c|}{ Dependent Variable: Transactional Leadership } \\
\hline Independent Variable & B & SE & $\boldsymbol{\beta}$ (Standardized) & B & SE & $\beta$ (Standardized) \\
\hline Klan & 0.199 & 0.085 & 0.210 & & & \\
\hline Adhocracy & 0.194 & 0.095 & 0.191 & & & \\
\hline Hierarchy & 0.253 & 0.082 & 0.236 & -0.124 & 0.054 & -0.200 \\
\hline Constant & 1.919 & 0.149 & & 2.451 & 0.148 & \\
\hline
\end{tabular}

"Transformational Leadership Style" was set as the dependent variable, and "Organizational Culture Types" as the independent variable of the analysis, the results of which indicate that the effect of culture on leadership is statistically significant (Culture $\beta: 0.414, p<0.05$; Clan Culture $\beta: 0.199, p<0.05$; Adhocracy Culture $\beta: 0.194, p<0.05$; Hierarchy Culture $\beta: 0.253, p<0.05$ ). "Transactional Leadership Style" was set as the dependent variable, and "Hierarchy Organizational Culture" as the independent variable of the analysis, the results of which indicate that the effect of culture on leadership is statistically significant (Hierarchy Culture $\beta:-0.124, \mathbf{p}<0.05)$ Hypothesis $\mathbf{H}_{\mathbf{2}}$ was therefore accepted.

$\mathbf{H}_{3}$ : Leadership style and organizational culture influence individual performance.

Table 8 demonstrates the relationship between the variables. A regression analysis was performed to measure the effect of "Leadership Style" and "Organizational Culture" on "Individual Performance". 
Table 8: Regression Analysis of Individual Performance in Relation to Leadership Style and Organizational Culture

\begin{tabular}{|l|c|c|c|}
\hline \multicolumn{4}{|l|}{ Dependent Variable: Individual Performance } \\
\hline Independent Variable & B & SE & $\beta$ (Standardized) \\
\hline Transformational Leadership & 0.269 & 0.049 & 0.346 \\
\hline Adhocracy Culture & -0.167 & 0.076 & -0.210 \\
\hline Hierarchy Culture & 0.204 & 0.067 & 0.244 \\
\hline Constant & 2.432 & 0.261 & \\
\hline
\end{tabular}

"Individual performance" was set as the dependent variable, and "Transformational Leadership" and "Adhocracy Culture and Hierarchy Culture" as the independent variables of the analysis, the results of which indicate that the effect of culture and leadership on individual performance is statistically significant. The effect of leadership on performance is stronger than that of culture on performance. The dimension of leadership has a stronger influence in the model (Transformational Leadership $\beta: 0.346$, $p<0.05$ and Adhocracy Culture $\beta:-0.210$, Hierarchy Culture $\beta: 0.244, p<0.05)$. Hypothesis $H_{3}$ was therefore accepted.

\section{CONCLUSION}

This study was conducted with the aim of investigating how employee performance is influenced by the organizational culture and leadership style perceptions of the head office employees of a private bank in Istanbul. It is anticipated that this study will contribute to the literature by illustrating the importance of the strong impact that the adoption of leadership styles appropriate for the organizational culture and for the business in general makes on employee performance.

There are many studies which examine leadership, organizational culture and employee performance separately. However, a review of the available literature suggests that there is limited research carried out in the field of banking and finance which takes into account the interaction of all these three variables.

The research results reveal a significant relationship between organizational culture, individual performance and leadership style. Furthermore, a significant relationship between individual performance and leadership was observed. In fact, the findings of Akman et al. (2015), Barney (1986), and Karayalçın (2009) also support the results here.

Thus, taking into account the relation that leadership style and organizational culture has with performance, it becomes clear that organizational culture plays an important role by providing support in times of change and holding employees together, which, in general, contribute to the corporation's ability to achieve its goals and objectives in an industry where change is rapid and competition is fierce. It is also interpreted that it is important to adopt leadership styles which more easily manage change through the use of appropriate methods to overcome resistance in ways that contribute to the personal growth of employees, keep total costs under control by using resources effectively, and attract audiences (personnel) to move toward defined strategic goals.

The results of this research suggest that the market type and the hierarchy type of organizational culture increase employee performance. This finding implies that employees perform relatively better when tasks are defined in line with rules, procedures, and policies, goals are openly shared with them, they are encouraged to compete over performance criteria, and are rewarded based on their performance. The clan-adhocracy culture is also observed to have a positive influence on employee performance (0,317).

Employee motivation tends to increase when a sense of solidarity and team spirit is prevalent in the work environment, and when leaders actively encourage employees and focus on building robust relationships with them. The results of this study indicate that employee performance is positively influenced by organizational culture but not by types of organizational culture. Bozoğlan (2010), Erdil et al. (2005), and Tüfekçi (2012) have also concluded that organizational culture influences performance.

In organizations where the hierarchy culture is dominant, rules and procedures prevail and employees are informed in advance and in detail about tasks and responsibilities that they are expected to carry out. They are rewarded when they achieve the defined goals. In cases where they do not, a penalty mechanism steps in. Similarly, transactional leaders are also work-oriented. They openly express their expectations of employees, focus on productivity, and offer rewards such as status or bonus to employees who meet the goals. The negative and weak correlation between hierarchy culture and transactional leadership can account for 
the possibility that employees working for an organization where the hierarchy culture is adopted, are by default working in a way that meets the defined expectations, sticking to established norms, policies, and methods.

A weak negative correlation also exists between the clan-adhocracy culture and transactional leadership, mainly because assertive behavior is encouraged in organizations with this type of culture. Employees are open to new possibilities, can express their ideas more openly, and are encouraged to take initiative. The work environment is dynamic and relationships are genuine. Employees are intrinsically motivated to put their effort into meeting the organization's goals, as a positive reflection of the sense of unity that they get from the work environment, and by virtue of their commitment to the organization and its customs. They do not need a mechanism of regulations or rewards.

As for transformational leaders; they build genuine relationships with employees and try to understand their needs and expectations, placing emphasis on their personal growth. They believe in the need for innovation and change, encouraging their employees to be assertive in that direction. In other words, they possess the qualities that promote the kind of dynamic work environment found in organizations where the clan and adhocracy cultures are adopted. This situation is also reflected in the research findings, which indicate that there is a positive correlation between the transformational-transactional leadership style and the clan-adhocracy culture type. Barut and Onay (2018), Bakan (2009), and Mamatoğlu (2005) also support the relationship between organizational culture and leadership.

Findings suggest that the relationship between leadership and employee performance is stronger for leaders who scored higher on the transformational style, when compared to transactional leaders. Transformational leaders tend to have a positive influence on the performance of their employees, mainly because they encourage creativity, show concern for personal development, and establish strong communication. The fact that leaders exert significant influential on performance also makes them relevant for the overall performance of the organization. Thus it is assumed important that leaders develop the aforementioned skills. This is because, as research results suggest, employee performance is negatively influenced by transactional leaders who stick to traditional practices, use reward-penalty mechanisms, and do not attend to the needs of employees unless a problem arises. Leaders who demonstrate this type of leadership style tend to restrain employees from being creative as they focus only on goals, hence putting their organization at the risk of falling behind in competition. Similar findings are available in the literature. Ay and Keleş (2017), Demirel (2017), Çekmecelioğlu (2014), and Çıpa (2014)'s findings all support the results obtained in this research. Incirkuş (2012), however, has found that there is not a significant correlation between the dimensions of transformational leadership and employee performance.

The results of the present study illustrate that the impact of organizational culture and leadership styles on employee performance is statistically significant, though the effect of leadership styles on employee performance is stronger than that of organizational culture on employee performance.

The research team's perceptions of the organizational culture, leadership, and individual performance were questioned across demographic variables. Age, level of education, professional experience, and gender were found to not account for any difference. While the findings of Güven (2018), Arman and Arpacı (2014), and Balay et al. (2013) support the findings of the present study, Bakan (2009) has obtained results suggesting a significant difference in the "leadership" and "organizational culture" perceptions of managers due to demographic variables.

In conclusion, the culture of an organization and especially the leadership styles adopted in it have a significant impact on employee performance, which in turn creates an effect on the organization's ability to gain a competitive edge against its rivals.

\section{REFERENCES}

Akman, V., Hanoğlu, M., and Kızıl, C. (2015). Liderlik ile personel performansı arasındaki ilişki üzerine bir şirket incelemesi. Elektronik Sosyal Bilimler Dergisi. 14 (52), p. 130-145.

Anderman, E., Smith, J., and Belzer, S. (1991). Teacher commitment and job satisfaction: The role of school culture and principal leadership. Paper Presented at The Annual Meeting of The American Educational Research Association.

Arman, M. and Arpacı, Ö. Y. (2014). Öğretim elemanları ve çalışanların örgüt kültürüne ilişkin algılamaları: Pamukkale üniversitesi’nde bir araştırma. Yenifikir Dergisi. 5 (2), p. 47-62. 
Aslan, M. (2017). Yönetici liderlik tarzları ile çalışan performansı arasındaki ilişki: Bir kargo şirketinde uygulama. Yüksek Lisans Tezi. İstanbul: Beykent Üniversitesi SBE.

Ay, F. A., and Keleş, K. (2017). Etkileşimci ve dönüşümcü liderlik tarzlarının işten ayrılma niyeti ve iş performansı üzerinde etkisi. Gümüşhane Üniversitesi Sağlık Bilimleri Dergisi. 6 (4), p. 193-203.

Bakan, İ. (2009). Liderlik tarzları ile örgüt kültürü türleri arasındaki ilişkiler: bir alan çalışması. TISK Akademi. 4 (7), p. 139-172.

Balay, R., Kaya, A., and Cülha, A. (2013). Örgüt kültürü ve örgütsel sinizm ilişkisi. Cumhuriyet Üniversitesi Iktisadi ve Idari Bilimler Dergisi. 14 (2), p.123-144.

Barney, J. B. (1986). Organizational culture: can it be a source of sustained competitive advantage? Academy Of Management Review, 11 (3), p. 656-665.

Barut, Y., and Onay, M. (2016). Örgüt kültürü ve liderlik tarzı arayışında, yeni argümanlar: Manisa vestel fabrikasında bir çalışma. Uluslararası Bilimsel Araştırmalar Dergisi. 3 (1), p. 181-193.

Bozoğlan, İ. T. (2010). Örgüt kültürünün performans kriterlerine etkisi ve tesco kipa uygulaması. Yüksek Lisans Tezi. İzmir: Dokuz Eylül Üniversitesi Sosyal Bilimleri Enstitüsü

Bülbül, S. E. and A. Köse (2010). Ülkelerin sosyoekonomik göstergelerle karşılaştırılmasında çok değişkenli tekniklerin kullanımı. İstanbul: Avcıol Basım Yayın.

Büyüköztürk, Ş. (2011). Sosyal Bilimler için Veri Analizi El Kitabı. Ankara: Pegem Akademi.

Çekmecelioğlu, H. G. (2014). Göreve ve insana yönelik liderlik tarzlarının örgütsel bağlılık, iş performansı ve işten ayrılma niyeti üzerindeki etkileri. Kocaeli Üniversitesi Sosyal Bilimler Enstitüsü Dergisi. (28), p. 21-34.

Çıpa, D. (2014). Örgüt kültürü ve dönüşümcü liderlik özelliklerinin öğretmen performansına etkisi üzerine İstanbul ilinde yapılan deneysel bir çalışma. Yüksek Lisans Tezi. İstanbul: Beykent Üniversitesi SBE.

Çokluk, Ö., Şekercioğlu, G. ve Büyüköztürk, Ş., (2010). Sosyal bilimler için çok değişkenli istatistik SPSS ve lisrel uygulamaları. Ankara: Pegem Akademi.

Demirel, Z. H. (2017). Yöneticilerin liderlik davranışlarının işgören performansı ile ilişkilerin incelenmesi: 5 yıldızlı otel işletmelerinde bir uygulama. Akademik Bakış Uluslararası Hakemli Sosyal Bilimler Dergisi. (62), p. 381-397.

Doğanay, A. (2014). Liderlik tarzlarının çalınanların bağlılık seviyesi ve performansına etkisi: Başakşehir Belediyesi’nde bir uygulama. Yüksek Lisans Tezi. İstanbul: İstanbul Gelişim Üniversitesi SBE.

Erdem, O. and Dikici, A. M. (2009). Liderlik ve kurum kültürü etkileşimi. Elektronik Sosyal Bilimler Dergisi. 8 (29), p. 198-213.

Erdil, O. Kitapcı, H., and Turan, E., (2010). Örgüt kültürünün kalite algısına ve işletme performansına etkisi. Atatürk Üniversitesi Iktisadi ve Idari Bilimler Dergisi. 19 (1), p. 259-273.

Gül, R. (2016). Liderlik tarzlarının örgüt kültürüne etkisi: Kamu kurumunda araştırma. Yüksek Lisans Tezi. Kars: Kafkas Üniversitesi SBE.

Güven, M. (2018). Örgütsel liderliğin örgütsel performansa etkileri bingöl özel ve kamu kurumları örneği. Journal of Social Sciences Institute/Sosyal Bilimler Enstitüsü Dergis. 8 (15), p. 261-279.

Karayalçın, E. (2009). Bankacılık sektöründe örgüt kültürü, liderlik ve firma (şube) performansı ilişkisi. Yüksek Lisans Tezi. İstanbul: Kadir Has Üniversitesi SBE.

Kılıç, G. (2006). Eğitim kurumlarında liderlik tarzları ve örgüt kültürünün performans üzerindeki etkisi. Yüksek Lisans Tezi. Kayseri: Erciyes Üniversitesi SBE.

Mamatoğlu, N. (2005). Kültür tipini yordayan lider davranışışları. Abant Izzet Baysal Üniversitesi Sosyal Bilimler Enstitüsü Dergisi. (2) 11, p. 165180.

Marks, D. E. (2002). A Study of Two Leadership Styles and School Cultural Norms in Small Middle Schools. Unpublished doctoral dissertation, Virginia Commonwealth University, Richmond, VA, USA.

Omira, O. B. (2015). "The Effect of Leadership Styles and Organizational Culture on Organizational Performance of the Public Sector in Saudi Arabia." Malaysia: Thesis Submitted to Othman Yeop Abdullah Graduate School of Business, Universiti Utara Malaysia, in Fulfilment of the Requirement for the Degree of Doctor of Philosophy.

Öztop, İ. (2008). Liderlik tarzları ve örgüt kültürü tipleri arasındaki ilişki ve bu ilişkinin nitel performans üzerine etkileri. Yüksek Lisans Tezi. Gebze: Gebze Yüksek Teknoloji Enstitüsü SBE. 
Öztürk, M. (2014). Örgüt kültürünün üretim işletmelerinin performansına etkisi: adana organize sanayi bölgesinde bir araştırma. Yüksek Lisans Tezi. Adana: Çukurova Üniversitesi SBE.Şahin, E. (2016). Özel öğretim kurumu yöneticilerin liderlik tarzlarının öğretmenlerin performansı üzerindeki etkisi. Yüksek Lisans Tezi. İstanbul: İstanbul Üniversitesi Eğitim Bilimleri Fakültesi

Tayfun A. ve Çatır O. (2013). Örgütsel Sessizlik ve Çalışanların Performansları Arasındaki Illişki Üzerine Bir Araştırma. İşletme Araştırmaları Dergisi. 5 (3), ss. 144-134.

Tüfekçi, N. (2012). Örgüt kültürünün örgüt performansına etkisinin hastaneler için akreditasyon standartları kapsamında ölçülmesi: Isparta ilindeki devlet, özel ve üniversite hastanesinde bir araştırma. Doktora Tezi. Isparta: Süleyman Demirel Üniversitesi Sosyal Bilimler Enstitüsü.

Yıldırım, C. (2000). Bilim Felsefesi. İstanbul: Remzi Kitabevi

Yurtkoru, E. S. (2001). The Role of Leadership in the Organizational Change Process. Doktora Tezi, İstanbul: Marmara Üniversitesi Sosyal Bilimler Enstitüsü.

Zakari, M., Poku, K., ve Owusu-Ansah, W. (2013). Organizational culture and organisational performance: Empirical evidence from the banking industry in Ghana. International Journal of Business, Humanities and Technolog. 3 (1), ss.95-107. 